\title{
Mill effect and dose-response relationships in byssinosis
}

\author{
R. N. JONES, J. E. DIEM, H. GLINDMEYER, V. DHARMARAJAN, \\ Y. Y. HAMMAD, J. CARR, AND H. WEILL
}

From the Pulmonary Diseases Section, Department of Medicine, Tulane University School of Medicine, New Orleans, Louisiana, 70112, USA

ABSTRACT Four hundred and eighty-six textile workers in three cotton mills and one wool/synthetic mill were studied for symptoms and functional effects of workroom exposure to dust. Byssinosis was found in $5.7 \%$ of 386 cotton workers, with an apparent threshold level of $0.5 \mathrm{mg}$ cotton dust $/ \mathrm{m}^{3}$ of air. Mean post-shift functional declines were greater in workers exposed to $\geq 0 \cdot 2 \mathrm{mg} / \mathrm{m}^{3}$. Workers with byssinosis were unequally distributed, however, with respect to job category and mill; and these variables, rather than current dust exposure levels, accounted for the observed distribution of byssinosis prevalence rates. Variation in biological potency of different samples of cotton dust could be responsible for 'mill effect', the residual variation in response rates by mill after controlling for variation due to dust exposure. A number of other potential influencing variables that are likely to be distributed unequally by mill should also be considered. Mill effect should be assessed in large-scale studies of byssinosis, most of which have analysed biological response rates by combining mill and other variables to examine first-order effects of dust dosage. In such analyses, much of the observed variability may be due to factors other than dust dosage.

The relationship between cotton dust exposure and respiratory illness is complicated, but many basic features were recognised more than one hundred years ago. For example, Leach (1863) stated that illness was more prevalent among workers in the early stages of processing cotton, in dustier work places, and in mills using lower grades of cotton. The disabling character of the chronic illness was noted, as was the healthful effect of providing adequate dust control. Despite this fund of sound observations, byssinosis remains an important cause of morbidity and disability. Progress in understanding the disease has been hindered by several problems (US Department of Health, Education and Welfare, 1974). There is no reliable assay for bioactivity of cotton dust. There is lack of agreement on a standard way to measure airborne dust levels. Detection of acute responses to cotton dust has depended heavily on questionnaire data. There is still uncertainty regarding the precise relationship of acute lung function abnormalities or symptoms to the chronic, disabling respiratory disease. There is no clinical marker to distinguish the chronic

Received for publication 11 September 1978 Accepted for publication 30 November 1978 disease from chronic airways obstruction ordinarily found in the general population.

The present study was undertaken to examine the effects of low current dust exposures, with inclusion of differing past exposures as an independent variable. The method of comparing effects of past exposures was to study mills with different histories of dust control. In examining byssinosis prevalence rates we observed that mill could be a significant influencing variable. Under certain circumstances, failure to control for this variable could lead to faulty analysis of relationships between dust dose and biological response.

\section{Methods}

\section{STUDY DESIGN}

This study was designed to detect and quantify adverse responses to low levels of dust generated in cotton textile mills. In order to examine effects of past cotton dust exposure levels, mills of three major textile manufacturing companies were selected with low current dust levels and with different past histories of dust generation. The mills are designated I to IV. Mill I had processed cotton for only four years and represented the combination of low cur- 
Table 1 Distribution of worker population

\begin{tabular}{|c|c|c|c|c|c|c|}
\hline \multirow[t]{2}{*}{ Mill } & \multirow[t]{2}{*}{ Original population } & \multirow[t]{2}{*}{ Non-participant } & \multicolumn{3}{|c|}{ Missing data } & \multirow[t]{2}{*}{ Complete } \\
\hline & & & Interview & Dust & Function & \\
\hline $\begin{array}{l}\text { I } \\
\text { II } \\
\text { IIIa } \\
\text { IIIb } \\
\text { IIIc } \\
\text { IV }\end{array}$ & $\begin{array}{r}95 \\
122 \\
60 \\
63 \\
68 \\
116\end{array}$ & $\begin{array}{r}5 \\
4 \\
1 \\
7 \\
1 \\
12\end{array}$ & $\begin{array}{l}1 \\
1\end{array}$ & $\begin{array}{l}1 \\
4\end{array}$ & $\begin{array}{l}6 \\
10 \\
13^{*} \\
12 \\
14^{*} \\
15\end{array}$ & $\begin{array}{r}83 \\
108 \\
46 \\
44 \\
52 \\
85\end{array}$ \\
\hline Total & 524 & 30 & & 6 & 70 & 418 \\
\hline
\end{tabular}

*Includes the one subject with missing interview data.

rent and absent past exposure. Mill II had processed cotton for many years but had only lately achieved satisfactory dust control, with recent concentrations of elutriated dust approximating $0.5 \mathrm{mg} / \mathrm{m}^{3}$ (the vertical elutriator rejects particles of diameter $\geq 15 \mu \mathrm{m})$. Mill III consisted of three geographically close installations in which cotton dust exposures had been low for at least ten years. Mill IV processed synthetics or wool-synthetic blends and was included as a control. Data on recent and past dust levels came from the industrial hygiene departments of the mills and were used to select the mills to be studied. Dust levels reported in this paper were obtained at the time of the respiratory health assessment and were measured by Tulane University personnel. Mill selection was dictated by the study design, and the three cotton mills studied were the only ones, among those of two participating manufacturers, that fulfilled design criteria. Neither company had transferred workers away from these mills on grounds of ill health.

Table 1 shows the distribution of the population in the four mills, and Table 2 the characteristics of the study population. (The sequential operations in cotton textile milling are shown later, in Table 4.) In Mills I, III, and IV, the total population of openers to warpers inclusive, was selected for study. The Mill II population was too large to study in the time allotted, so all workers in preparation jobs (opening to roving inclusive) were selected, and the group in spinning, winding, and twisting was sampled using a simple random sample.

For inclusion in the study, a subject must have worked for at least one year in the mill. In the control mill (Mill IV), those who had in the past worked 12 or more months in cotton mills, were excluded. The population so defined consisted of 524 potential study participants. In addition to the above requirements, each participant must have been off work for at least 35 hours before pre-shift testing on Monday, and must have worked at least five hours before post-shift testing.

Four people were disqualified for not having been off work long enough, and another 26 did not participate because of illness or other reasons. The non-participation rate was $5.7 \%$. Of the 494 remaining, six could not be assigned to measured dust exposure categories, and two had incomplete interviews: 486 were analysed for questionnaire responses. For analysis of pulmonary function data, 418 subjects were available: 494, less six without dust measurements, less 70 with unsatisfactory pulmonary function data.

\section{ENVIRONMENTAL MEASUREMENTS}

We measured dust levels in accordance with specifications of the National Institute of Occupational Safety and Health (NIOSH) criteria document for a cotton dust standard (US Department of Health, Education, and Welfare, 1974). The collecting instruments were Lumsden-Lynch vertical elutriators. Most of these were modified with a $\mathrm{T}$ in the pump tubing to permit simultaneous collection of total and elutriated dust samples. All the vertical elutriators were calibrated before sampling in each mill: the critical orifices used to control flow rates were calibrated against a flow meter, and the meter was calibrated against a spirometer and stop-watch. All pumps were shown to provide a vacuum of at least $381 \mathrm{mmHg}$. Flow rates of the elutriators

Table 2 Characteristics of study population

\begin{tabular}{|c|c|c|c|c|c|c|}
\hline Mill & Number of subjects & Mean age $(y r)$ & Mean years in cotton mills & $\%$ smokers & $\%$ blacks & $\%$ men \\
\hline $\begin{array}{l}\text { I } \\
\text { II } \\
\text { III } \\
\text { IV }\end{array}$ & $\begin{array}{r}89 \\
118 \\
179 \\
100\end{array}$ & $\begin{array}{l}38 \cdot 1 \\
38.8 \\
39.9 \\
36.4\end{array}$ & $\begin{array}{r}3 \cdot 8 \\
10 \cdot 1 \\
15 \cdot 3 \\
-\end{array}$ & $\begin{array}{l}52 \cdot 8 \\
66.9 \\
64.8 \\
38.0\end{array}$ & $\begin{array}{l}31 \cdot 5 \\
59 \cdot 3 \\
44 \cdot 7 \\
51 \cdot 0\end{array}$ & $\begin{array}{l}47 \cdot 2 \\
73 \cdot 7 \\
63 \cdot 1 \\
46 \cdot 0\end{array}$ \\
\hline
\end{tabular}


were between 6.8-7.2 litre/min (except one with a flow rate of $7.6 \mathrm{litre} / \mathrm{min}$ ) as opposed to the recommended rate of $7 \cdot 4 \pm 0 \cdot 2 \mathrm{litre} / \mathrm{min}$. This does not significantly affect measurements because the $7.4 \mathrm{litre} / \mathrm{min}$ rate rejects particles with a diameter greater than $15 \mu \mathrm{m}$, and the 6.8-7.2 litre/min range rejects particles with a diameter greater than 14.4 $14.8 \mu \mathrm{m}$ (for spherical particles of unit density, according to the Stokes equation).

Sampling was done simultaneously in each distinct operational area such as opening, picking, carding, or spinning. The elutriators were suspended from posts in sampling sites representative of the areas monitored and free from unnatural draughts. Sampler inlets were positioned abcut $1.5 \mathrm{~m}$ above floor level. The duration of sampling was 5-8 h. All samples were collected on weighed $37 \mathrm{~mm}$ membrane filters of the same batch (Metricel VM-1, Gelman Instrument Co.) held in standard threepiece cassette assemblies (Millipore Corporation). Membrane pore size was $5.0 \mu \mathrm{m}$. For total dust collection, the top section of the cassette was modified by an $11.68 \mathrm{~mm}$ hole through which air was drawn at approximately $5 \mathrm{litre} / \mathrm{min}$, under which conditions the face velocity is similar to that in an $20 \times 25 \mathrm{~cm}$ high-volume sampler. Each filter was weighed before and after sample collection on a calibrated balance with a sensitivity of $0.01 \mathrm{mg}$. Filters were equilibrated in the laboratory for $24 \mathrm{~h}$ before each weighing under conditions of similar temperature and relative humidity. For every 10 samples, a control filter was subjected to similar handling but without dust collection, and the average weight change of control filters was used to correct weight changes of the sample filters.

Four hundred and eighty-one samples were collected during textile production in the six installations: these comprised 261 elutriated samples and 220 total dust samples. Twenty-nine samples were collected in work areas before production was started.

\section{ASSESSMENT OF SYMPTOMS}

The Medical Research Council questionnaire (1960), modified for detecting byssinosis, was administered by three trained interviewers. Subjects were interviewed either before or after work on Monday. Those who had ever regularly smoked cigarettes were considered to be smokers and all others were considered to be non-smokers. 'Preparation' jobs included opening to roving, inclusive. Byssinosis was classified according to the criteria of Schilling et al. (1955b; 1963): chest tightness, sometimes on Monday, always on Monday, or on Monday and later in the working week. An individual was considered to have chronic byssinosis if he or she did not currently have Monday symptoms but recalled having these in the past, and currently had chronic ailments affecting the lower respiratory tract. Chronic bronchitis was defined as cough and phlegm on most days for at least three months in the year, during the past two or more years. Dyspnoea was defined as breathlessness when hurrying along level ground or when walking up a slight hill.

\section{LUNG FUNCTION TESTING}

Ventilatory function measurements were made with three dry rolling-seal spirometers (CPI 220, Cardiopulmonary Instruments, Houston, Texas) having electronic systems providing graphic and digital displays of volume, time, and flow. The instruments were calibrated for volume, time, and flow before each testing session. Three technicians from the Tulane centre administered the tests; each used the same spirometer at each session, and the same technician and instrument were used for each subject in the pre- and post-shift testing sessions. The protocol for each session consisted of four $7 \mathrm{~s}$ forced expiratory vital capacity manoeuvres performed in the standing position using a nose clip. Each manoeuvre provided the following measurements: forced vital capacity (FVC), forced expiratory volume in $0.5 \mathrm{~s}\left(\mathrm{FEV}_{0.5}\right)$, and in $1 \mathrm{~s}\left(\mathrm{FEV}_{1.0}\right)$, forced expiratory flow over $25-75 \%$ of $F V C\left(F^{2} F_{25-75}\right)$, and maximum expiratory flow at $50 \%\left(\mathrm{FEF}_{50}\right)$ and $25 \%\left(\mathrm{FEF}_{25}\right)$ of FVC. The latter two measurements were derived from instantaneous flow rates on the maximum expiratory flow-volume curve. These two flow rates, and the $\mathrm{FEF}_{25-75}$, were determined using iso-volume methods, i.e., were computed for the largest FVC whether it occurred in pre-shift or post-shift testing. For relation to predicted values, the standing height was measured to the nearest quarter-inch without shoes on a medical scale.

Fifty-four subjects gave sub-maximal efforts, and their test results were excluded from further analysis. Criteria included non-repeatability, start from submaximal inspiration, slow start, and failure to sustain maximum expiratory effort. An additional 16 subjects declined, or were unable, to take the test for reasons such as tuberculosis, tooth extraction, upper respiratory infections, and asthma attack (one subject, in whom the attack occurred before coming to the mill on Monday).

For selection of test values to analyse, the two expirations yielding the highest combined $\mathrm{FEV}_{\mathbf{0 . 5}}$ and $F_{2 E F}$ 25-75 (as the percentage of predicted values) were chosen, with the requirement that each expiration yielded an FVC within 3\% of the largest FVC. The data from the selected expirations were then averaged and stored for analysis. 
Table 3 Variables affecting dust levels in cotton textile mills

\begin{tabular}{|c|c|c|c|c|c|}
\hline \multirow{2}{*}{ Variable } & \multicolumn{5}{|l|}{ Mill } \\
\hline & $I$ & II & IIIa & $I I I b$ & IIIC \\
\hline Cotton grade & Bright low middling & $\begin{array}{l}\text { Low middling spot, } \\
\text { middling spot, strict } \\
\text { low middling spot }\end{array}$ & Strict middling & $\begin{array}{l}\text { Strict low middling } \\
\text { bright }\end{array}$ & $\begin{array}{l}\text { Strict low middling } \\
\text { bright, low middling } \\
\text { bright }\end{array}$ \\
\hline Average yarn count & $17 \cdot 9$ & 6.9 & 44 & 35 & $33 \cdot 4$ \\
\hline Per cent cotton in blends & 100 & 85 & 35 & 50 & 50 \\
\hline Temperature $\left({ }^{\cap} \mathbf{F}\right)$ & 80 & 80 & $78-80$ & $77-78$ & $77-84$ \\
\hline Relative humidity ( $\%$ ) & 45 & 50 & $32-46$ & 47-53 & $43-57$ \\
\hline Air changes per hour & $5-25$ & $5-25$ & $10-27$ & $7-24$ & $8-14$ \\
\hline Card speed (pounds/hour) & 75 & 104 & $4 \cdot 5$ & 30 & 30 \\
\hline Filter system for return air & Vee screen & Rotary drum & Vee screen & Rotary drum & Rotary drum \\
\hline Filter media & Non-woven & Woven & Non-woven & Non-woven & Non-woven \\
\hline
\end{tabular}

Results

\section{DUST MEASUREMENTS}

Some variables affecting dust levels in the cotton mills are given in Table 3 . Mill II uses lower grade cotton, has the lowest average yarn count, uses a higher percentage of cotton in their blends and processes fibre at a much higher rate than the other mills. All these factors would tend to increase the dust level in Mill II, and this was confirmed by our measurements.

A summary of the average elutriated dust levels at various locations in the four mills is given in Table 4. Each sampling site was sampled three times on the same day (one sample per shift). The 'number' in Table 4 refers to the total number of samples for all three shifts at different sampling sites within a designated job area. The dust levels in the opening, picking, blending, distribution and carding areas are generally higher than in the subsequent processing areas such as drawing, roving, combing, spinning, winding, twisting, spooling and warping. Wide variations were found in the dust levels between different sampling sites within the same operational area, and also at the same site during different shifts. There was no consistent pattern in the variation of dust levels by sampling site or shift. The control mill (Mill IV), which processes only synthetics, had uniformly low ( $\geq 0.17 \mathrm{mg} / \mathrm{m}^{3}$ ) average elutriated dust levels and showed only minor variations by site, job area and shift.

Fifteen elutriated dust samples collected before work started in the picking, opening and carding areas of Mill II and Mill III averaged $0.08 \mathrm{mg} / \mathrm{m}^{3}$ with a range of $0.01-0.17 \mathrm{mg} / \mathrm{m}^{3}$.

\section{SYMPTOMS}

Table 2 shows demographic characteristics of the 486 subjects. Of 386 cotton mill workers, $22(5 \cdot 7 \%)$ had byssinosis symptoms according to the primary definition. Three of $\mathbf{1 0 0}$ workers in the control mill gave answers defining byssinosis. The distribution of workers with byssinosis, in each cotton mill and in three current dust exposure categories, is shown in Table 5 (the number with byssinosis as the numerator, and the total in each cell as the denominator). Each worker was assigned to one of the three categories according to the measured level of

Table 4 Dust measurements by job area in four textile mills: mean values, standard deviations, and number of samples taken

\begin{tabular}{|c|c|c|c|c|c|c|}
\hline \multirow[t]{2}{*}{ Job area } & \multicolumn{6}{|c|}{ Mean elutriated dust in $\mathrm{mg} / \mathrm{m}^{3}, \pm S D$ (number) } \\
\hline & Mill I & Mill II & Mill IIIa & Mill IIIb & Mill IIIc & Mill IV \\
\hline $\begin{array}{l}\text { Opening } \\
\text { Blending } \\
\text { Picking } \\
\text { Distribution } \\
\text { Carding } \\
\text { Drawing } \\
\text { Roving } \\
\text { Combing } \\
\text { Spinning } \\
\text { Winding } \\
\text { Twisting } \\
\text { Spooling } \\
\text { Warping } \\
\text { Waste house }\end{array}$ & $\begin{array}{l}0.48 \pm 0.18(6) \\
0.47 \pm 0.04(9) \\
0.50 \pm 0.11(6) \\
0.47 \pm 0.10(6) \\
0.46 \pm 0.23(6) \\
0.22 \pm 0.05(6) \\
0.38 \pm 0.10(3) \\
0.46 \pm 0.17(3)\end{array}$ & $\begin{array}{l}2.43 \pm 0.87(6) \\
6.36 \pm 4.73(6) \\
1.70 \pm 0.50(6) \\
0.76 \pm 0.13(6) \\
1.08 \pm 0.52(9) \\
0.44 \pm 0.08(6) \\
0.40 \pm 0.06(6) \\
0.51 \pm 0.24(3) \\
0.20 \pm 0.14(3) \\
6.53 \pm 0.69(3)\end{array}$ & $\begin{array}{l}0.50 \pm 0.15(3) \\
0.48 \pm 0.11(3) \\
0.58 \pm 0.24(6) \\
0.12 \pm 0.08(3) \\
0.14 \pm 0.13(3) \\
0.08 \pm 0.05(9)\end{array}$ & $\begin{array}{l}0.73 \pm 0.24 \\
0.29 \pm 0.09 \\
0.73 \pm 0.50 \\
0.24 \pm 0.08 \text { (3) } \\
0.26 \pm 0.07 \text { (3) } \\
0.33 \pm 0.10 \text { (3) } \\
0.20 \pm 0.16 \text { (12) }\end{array}$ & $\begin{array}{l}0.54 \pm 0.06 \\
0.83 \pm 0.21 \\
0.40 \pm 0.14 \\
0.20 \pm 0.03 \\
0.12 \pm 0.07 \\
0.13 \pm 0.10\end{array}$ & $\begin{array}{l}0.15 \pm 0.07(6) \\
0.11 \pm 0.04(9) \\
0.14 \pm 0.01(3) \\
0.17 \pm 0.08(9) \\
0.16 \pm 0.04(9) \\
0.14 \pm 0.03(6)\end{array}$ \\
\hline
\end{tabular}


Table 5 Distribution of byssinotics (all grades) by mill and by current dust exposure category

\begin{tabular}{llll}
\hline Smoking status & \multicolumn{2}{l}{ Current dust exposure category } \\
\cline { 2 - 4 } & $\begin{array}{lll}\text { High } \\
\begin{array}{l}\text { Intermediate } \\
<0.5 \mathrm{mg} / \mathrm{m}^{3}\end{array}\end{array}$ & $\begin{array}{l}\text { Low } \\
<0.5 \geq 0.2 \mathrm{mg} / \mathrm{m}^{3}\end{array}$ & $<0.2 \mathrm{mg} / \mathrm{m}^{3}$ \\
\hline Smokers & & & \\
$\quad$ Mill I & $0 / 12$ & $1 / 34$ & $0 / 1$ \\
Mill II & $14 / 69$ & $1 / 10$ & $-1 /$ \\
Mill III & $1 / 23$ & $1 / 46$ & $1 / 47$ \\
Non-smokers & $0 / 16$ & $0 / 22$ & $0 / 4$ \\
Mill I & $2 / 24$ & $1 / 15$ & $-/-$ \\
Mill II & $0 / 16$ & $0 / 19$ & $0 / 28$ \\
Mill III & $0 / 19$ & \\
\hline
\end{tabular}

elutriated dust in his own work area. These categories were: high, $0.5 \mathrm{mg} / \mathrm{m}^{3}$ or greater; intermediate, less than 0.5 but at least $0.2 \mathrm{mg} / \mathrm{m}^{3}$; and low, less than $0.2 \mathrm{mg} / \mathrm{m}^{3}$.

Seventeen subjects, of whom 16 were smokers, had symptoms defined as chronic bronchitis. Nine were employed in Mill II, six in Mill III, and two in Mill IV (one of whom was the non-smoker).

Only one person fulfilled the criteria for chronic byssinosis. He was 34 years old, recalled past symptoms of byssinosis and now has chronic cough and phlegm.

Byssinosis prevalence was analysed using hierarchical log-linear modelling, assuming that the number of study participants in each exposuresmoking category was fixed by design. Table 6 shows the observed rate for each exposure level, for smokers and non-smokers, followed by an estimated byssinosis rate. These estimated rates were derived

Table 6 Observed and estimated rates of byssinosis (all grades) by exposure category

\begin{tabular}{lllll}
\hline Smoking status & \multicolumn{3}{l}{ Current dust exposure category } \\
\cline { 2 - 5 } & $\begin{array}{l}\text { High } \\
\geq 0.5 \mathrm{mg} / \mathrm{m}^{3}\end{array}$ & $\begin{array}{l}\text { Intermediate } \\
<0.5 \geq 0.2 \mathrm{mg} / \mathrm{m}^{3}\end{array}$ & $\begin{array}{l}\text { Low } \\
<0.2 \mathrm{mg} / \mathrm{m}^{3}\end{array}$ & $\begin{array}{l}\text { Control } \\
(--)\end{array}$ \\
\hline Smokers & & & & \\
Observed (\%) & 14.4 & 3.3 & $2 \cdot 1$ & 2.6 \\
Estimated (\%) & 13.5 & 3.6 & 1.7 & 4.9 \\
(Number) & $(104)$ & $(90)$ & $(48)$ & $(38)$ \\
Non-smokers & & & & \\
Observed (\%) & 3.6 & 1.8 & 0 & 3.2 \\
Estimated (\%) & 5.3 & 1.3 & 0.6 & 1.8 \\
(Number) & $(56)$ & $(56)$ & $(32)$ & $(62)$ \\
\hline
\end{tabular}

from a log-linear model that specified dependence ( $P=0.56$ for goodness of fit as measured by $-2 \mathrm{log}$ likelihood ratio statistic) on exposure level and smoking, without interaction between these variables. In this analysis, the prevalence of byssinosis is significantly $(P=0.005)$ affected by exposure level beyond the effect of smoking.

The above analysis, however, rests on the assumption that given dust levels define homogeneous exposure level categories, and disregards potentially important variables associated with the individual mills. This assumption has been made in most of the published studies of dust exposure and byssinosis prevalence, and may be appropriate where prevalence rates are similar in the individual mills. In the present study, the prevalence rates are: Mill I, $1.1 \%$; Mill II, 15.3\%; Mill III, 1.6\%; and Mill IV, 3.0\%. Clearly, Mill II has a substantial effect upon the overall byssinosis rate, and this effect cannot be ignored in analysing the dose-response relationship.

To further explore the relationships between byssinosis and the mill and exposure variables, we performed an analysis (of cotton workers only) to determine the effects of mill, current dust exposure level, smoking, job category, and length of employment in cotton mills. Seven of the 386 cotton workers could not be assigned exclusively to either the preparation (opening to roving, inclusive) or later job categories, so the number of subjects for analysis was 379 . The aim was to identify those variables that accounted for the largest proportion of observed variability in byssinosis prevalence, and then to fit a log-linear model that included those variables, using maximum likelihood estimation. The identification of relevant variables follows closely the ideas of Higgins and Koch (1977), with the exception that exact methods for analysing two by two by $t$ contingency tables were used. The small data set led to the use of the exact method analogues of Higgins and Koch's 'termination statistic b' as opposed to 'termination statistic a'. When the variable tested singly for inclusion into the model contained more than two levels, these levels were combined to produce a bisected variable.

Table 7 shows the first-order relationships of the

Table 7 First-order relationships between byssinosis and explanatory variables

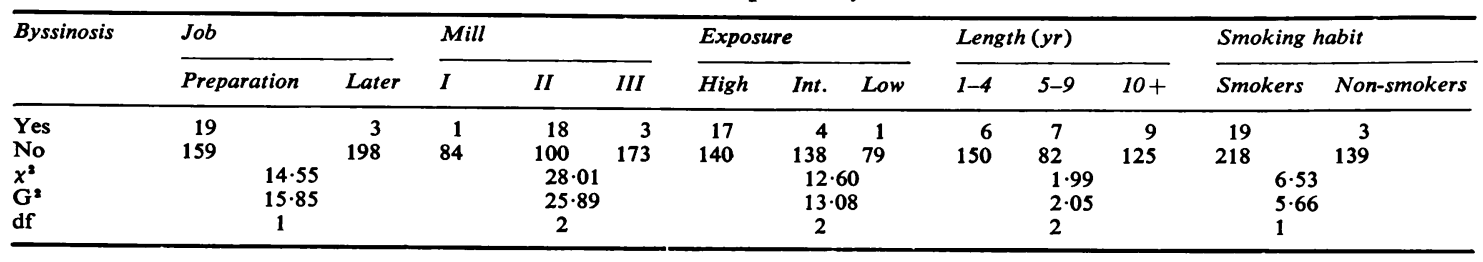


explanatory variables (before bisection) and byssinosis, together with the Pearson $\chi^{2}$ and the likelihood ratio $\mathrm{G}^{2}$. Based on $\chi^{2}$ or $\mathrm{G}^{2}$ per degree of freedom, the variables job and mill have the greatest effect on byssinosis prevalence. Because the magnitudes of these two effects are similar, the effects of all other explanatory variables beyond each (mill, and then job) were tested using the exact conditional maximum likelihood estimate of the combined odds ratio, using the computer program of Thomas (1975). When using mill to define strata, job had the largest effect, and when using job to define strata, mill had the largest effect. The next model therefore included both variables: after controlling for mill and job, the effect of smoking is significant at the level $P=0.06$, and smoking was therefore included in the final model. The fit of that model, specifying that the prevalence of byssinosis depends on mill, job, and smoking, was significantly better than the fit of any simpler model. Current dust exposure level $(P=1.0)$ and length of employment $(P=0.40)$ were not significantly explanatory variables.

Because these results were not anticipated, another analysis was performed to assess significance of mill against job, length of employment, smoking, and exposure level. These variables were jointly used to define strata, resulting in 36 tables $(2$ job $\times 3$ length $\times 2$ smoking $\times 3$ exposure categories). A number of these tables had zero marginal sums and thus did not contribute to the test statistic. Using the methods of Thomas (1975) an exact test was applied to determine whether the combined odds ratio was significantly different from 1 . For mill, the estimated ratio was $5 \cdot 30$, which is consistent with significant mill effect beyond the other variables $(P=0.02)$.

It should be noted, however, that the ability to discern a significant effect of exposure level beyond mill and job category was undoubtedly precluded by the strong associations between exposure level and those variables. Preparation workers in Mill II had the highest prevalence of byssinosis, but these workers were all in the high exposure level category; significantly more non-preparation workers were in the intermediate-low category. Table 8 shows the
Table 8 Distribution of subjects by exposure level, job category and mill

\begin{tabular}{|c|c|c|c|c|}
\hline \multirow[b]{2}{*}{ Mill } & \multicolumn{4}{|c|}{ Current dust exposure category } \\
\hline & $\begin{array}{l}\text { High } \\
\geq 0.5 \mathrm{mg} / \mathrm{m}^{2}\end{array}$ & $\begin{array}{l}\text { Intermediate } \\
<0.5 \geq 0.2 \mathrm{mg} / \mathrm{m}^{\mathrm{s}}\end{array}$ & $\underset{<0 \cdot 2 \mathrm{mg} / \mathrm{m}^{3}}{\operatorname{Low}}$ & Totals \\
\hline \multicolumn{5}{|l|}{ I } \\
\hline $\begin{array}{l}\text { Preparation } \\
\text { Later }\end{array}$ & $\begin{array}{r}3 \\
23\end{array}$ & $\begin{array}{r}8 \\
46\end{array}$ & $\begin{array}{l}1 \\
4\end{array}$ & $\begin{array}{l}12 \\
73\end{array}$ \\
\hline \multicolumn{5}{|l|}{ II } \\
\hline $\begin{array}{l}\text { Preparation } \\
\text { Later }\end{array}$ & $\begin{array}{r}87 \\
6\end{array}$ & $\begin{array}{r}0 \\
25\end{array}$ & $\begin{array}{l}\mathbf{0} \\
\mathbf{0}\end{array}$ & $\begin{array}{l}87 \\
31\end{array}$ \\
\hline \multicolumn{5}{|l|}{ III } \\
\hline $\begin{array}{l}\text { Preparation } \\
\text { Later }\end{array}$ & $\begin{array}{r}38 \\
0\end{array}$ & $\begin{array}{l}40 \\
23\end{array}$ & $\begin{array}{r}1 \\
74\end{array}$ & $\begin{array}{l}79 \\
97\end{array}$ \\
\hline $\begin{array}{l}\text { Totals } \\
\text { Preparation } \\
\text { Later }\end{array}$ & $\begin{array}{r}157 \\
128 \\
29\end{array}$ & $\begin{array}{r}142 \\
48 \\
94\end{array}$ & $\begin{array}{r}80 \\
2 \\
78\end{array}$ & 379 \\
\hline
\end{tabular}

numbers in preparation and later jobs, categorised by exposure level and by mill. Eighty-one per cent of the 157 in preparation jobs are also in the high dust exposure category, and only $1.1 \%$ in the lowexposure category. Half of the preparation workers and $59 \%$ of workers in high dust exposure are in Mill II. The only mill with substantial numbers in the low-exposure category is Mill III. The effect is a confounding of exposure with mill and job, and these data do not permit identification of an independent relationship of dust exposure level to prevalence of byssinosis.

\section{LUNG FUNCTION}

Four hundred and eighteen workers had complete lung function data for analysis of baseline (pre-shift) values and changes over the working shift. Of these, 333 were cotton workers and 85 worked in the control mill. Seven of the cotton workers could not be assigned to preparation or later job categories. Table 9 presents mean values for baseline function and shift changes, categorised by fibre type and by smoking status. Table 10 shows mean values categorised by mill, by current dust exposure levels, and by smoking.

Table 11 shows $P$ values for tests of significance for the influencing variables. Using methods described by Barr et al. (1976) partial F tests to

Table 9 Mean lung function values by fibre type and smoking

\begin{tabular}{|c|c|c|c|c|c|c|c|c|c|}
\hline \multirow[t]{2}{*}{ Fibre type } & \multicolumn{4}{|c|}{$\begin{array}{l}\text { Baseline lung function in percentage of predicted } \\
\text { values }\end{array}$} & \multicolumn{5}{|c|}{$\begin{array}{l}\text { Lung function changes over the working shift in litres }(F V C) \\
\text { or litres/second }\end{array}$} \\
\hline & $F V C$ & $F E V_{1 \cdot 0}$ & $F E F_{25-75}$ & $F E V_{1.0} / F V C, \%$ & $\triangle F V C$ & $\triangle F E V_{1 \cdot 0}$ & $\triangle F E F_{25-75}$ & $\triangle F E F_{50}$ & $\triangle F E F_{25}$ \\
\hline \multicolumn{10}{|l|}{ Cotton } \\
\hline 215 smokers & 107 & 99 & 82 & 77 & -0.045 & -0.040 & -0.153 & -0.111 & -0.055 \\
\hline 118 non-smokers & 108 & 102 & 94 & 80 & -0.036 & -0.029 & $-0 \cdot 136$ & -0.066 & -0.074 \\
\hline \multicolumn{10}{|l|}{ Synthetic } \\
\hline 53 non-smokers & 106 & $\begin{array}{l}102 \\
100\end{array}$ & $\begin{array}{l}91 \\
94\end{array}$ & $\begin{array}{l}80 \\
81\end{array}$ & $\begin{array}{l}-0.065 \\
-0.013\end{array}$ & $\begin{array}{c}-0.053 \\
0.004\end{array}$ & $\begin{array}{l}-0.223 \\
-0.042\end{array}$ & $\begin{array}{c}-0.009 \\
0.053\end{array}$ & $\begin{array}{r}-0.088 \\
0.003\end{array}$ \\
\hline
\end{tabular}


Table 10 Mean lung function values by mill, current dust exposure category, and smoking

\begin{tabular}{|c|c|c|c|c|c|c|c|c|c|}
\hline \multirow[t]{2}{*}{ Variable } & \multicolumn{4}{|c|}{$\begin{array}{l}\text { Baseline lung function in percentage of predicted } \\
\text { values }\end{array}$} & \multicolumn{5}{|c|}{$\begin{array}{l}\text { Lung function changes over the working shift in litres }(F V C) \\
\text { or litres/second }\end{array}$} \\
\hline & $F V C$ & $F E V_{1.0}$ & $F E F_{25-75}$ & $F E V_{1.0} / F V C, \%$ & $\triangle F V C$ & $\triangle F E V_{1 \cdot 0}$ & $\triangle F E F_{25-78}$ & $\triangle F E F_{\mathrm{BO}}$ & $\triangle F E F_{25}$ \\
\hline \multicolumn{10}{|l|}{ Mill } \\
\hline $\begin{array}{l}\text { I } \\
\text { II } \\
\text { III } \\
\text { IV }\end{array}$ & $\begin{array}{l}109 \\
108 \\
105 \\
107\end{array}$ & $\begin{array}{r}103 \\
100 \\
99 \\
101\end{array}$ & $\begin{array}{l}93 \\
83 \\
87 \\
93\end{array}$ & $\begin{array}{l}80 \\
77 \\
78 \\
80\end{array}$ & $\begin{array}{l}-0.024 \\
-0.047 \\
-0.046 \\
-0.033\end{array}$ & $\begin{array}{l}-0.033 \\
-0.022 \\
-0.049 \\
-0.017\end{array}$ & $\begin{array}{l}-0.105 \\
-0.118 \\
-0.193 \\
-0.111\end{array}$ & $\begin{array}{l}-0.078 \\
-0.057 \\
-0.132 \\
-0.029\end{array}$ & $\begin{array}{l}-0.061 \\
-0.001 \\
-0.110 \\
-0.031\end{array}$ \\
\hline \multicolumn{10}{|l|}{ Exposure level* } \\
\hline $\begin{array}{l}\text { High } \\
\text { Intermediate } \\
\text { Low }\end{array}$ & $\begin{array}{l}107 \\
109 \\
105\end{array}$ & $\begin{array}{r}100 \\
102 \\
97\end{array}$ & $\begin{array}{l}84 \\
91 \\
86\end{array}$ & $\begin{array}{l}78 \\
79 \\
78\end{array}$ & $\begin{array}{l}-0.046 \\
-0.046 \\
-0.021\end{array}$ & $\begin{array}{l}-0.035 \\
-0.049 \\
-0.011\end{array}$ & $\begin{array}{l}-0.148 \\
-0.164 \\
-0.107\end{array}$ & $\begin{array}{l}-0.107 \\
-0.098 \\
-0.058\end{array}$ & $\begin{array}{l}-0.030 \\
-0.087 \\
-0.084\end{array}$ \\
\hline \multicolumn{10}{|l|}{ Smoking * } \\
\hline $\begin{array}{l}\text { Smokers } \\
\text { Non-smokers }\end{array}$ & $\begin{array}{l}107 \\
108\end{array}$ & $\begin{array}{l}100 \\
102\end{array}$ & $\begin{array}{l}84 \\
94\end{array}$ & $\begin{array}{l}78 \\
80\end{array}$ & $\begin{array}{l}-0.047 \\
-0.029\end{array}$ & $\begin{array}{l}-0.041 \\
-0.018\end{array}$ & $\begin{array}{l}-0 \cdot 162 \\
-0 \cdot 107\end{array}$ & $\begin{array}{l}-0.098 \\
-0.029\end{array}$ & $\begin{array}{l}-0.060 \\
-0.050\end{array}$ \\
\hline
\end{tabular}

* Cotton workers only.

Table 11 P values for tests of significance of each explanatory variable beyond effects of the other variables

\begin{tabular}{|c|c|c|c|c|c|c|}
\hline Test & Mill & Level of exposure & Smoking & $J o b$ & Age & Length of exposure \\
\hline 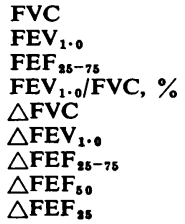 & $\begin{array}{l}0.35 \\
0.98 \\
0.24 \\
0.44 \\
0.17 \\
0.02 \\
0.02 \\
0.18 \\
0.04\end{array}$ & $\begin{array}{l}0.34 \\
0 \cdot 23 \\
0 \cdot 14 \\
0.49 \\
0 \cdot 11 \\
0.008 \\
0.03 \\
0 \cdot 24 \\
0.45\end{array}$ & $\begin{array}{l}0.45 \\
0 \cdot 16 \\
0.01 \\
0.006 \\
0 \cdot 46 \\
0 \cdot 24 \\
0.45 \\
0 \cdot 29 \\
0.89\end{array}$ & $\begin{array}{l}0.08 \\
0.89 \\
0.33 \\
0.60 \\
0.34 \\
0.52 \\
0.17 \\
0.40 \\
0.44\end{array}$ & $\begin{array}{l}0.84 \\
0.14 \\
0.0001 \\
0.0001 \\
0.70 \\
0.31 \\
0.05 \\
0.78 \\
0.09\end{array}$ & $\begin{array}{l}0.04 \\
0.03 \\
0.04 \\
0.31 \\
0.99 \\
0.63 \\
0.41 \\
0.93 \\
0.53\end{array}$ \\
\hline
\end{tabular}

assess the significance of a particular variable beyond the effects of other variables were performed in the context of a model that included the main effects of mill, current exposure level, smoking and job, and the quantitative variables of age and length of exposure.

For tests of baseline lung function, mill, current level of exposure, and job do not have significant effects at the level $\mathbf{P}=\mathbf{0} \cdot 05$. Smoking has a significant effect on the $\mathrm{FEF}_{25-75}(\mathrm{P}=0.01)$ and $\mathrm{FEV}_{1.0} / \mathrm{FVC}, \%(P=0.006)$. Length of exposure has significant effects on the FVC $(P=0.04)$, FEV $_{1.0}(P=0.03)$, and $F_{E F} F_{25-75}(P=0.04)$. Age has significant $(P=0.0001)$ effects on the $F_{E F} F_{25-75}$ and $\mathrm{FEV}_{1.0} / \mathrm{FVC}, \%$.

For changes in lung function over the working shift, mill has a significant effect on $\triangle F E V_{1.0}$ $(P=0.02), \triangle F E F_{25-75}(P=0.02)$, and $\triangle F E F_{25}$ $(P=0.04)$, the largest mean declines occurring in Mill III. Current levels of exposure have significant effect on $\triangle F E V_{1.0}(P=0.008)$ and $\triangle F E F_{25-75}$ $(P=0.03)$, the largest mean declines occurring in the intermediate exposure category. Age has significant effect only on $\triangle F_{25-75}(P=0.05)$. Smoking, job and length of exposure to cotton dust have no significant effect on shift changes.

\section{Discussion}

In the 1950 s, a number of studies, primarily by Schilling and various colleagues (Schilling, 1950, 1956; Schilling et al., 1955a, b; Roach and Schilling, 1960), demonstrated the extent and severity of byssinosis in textile mills. This led to new standards for permissible exposure, and to the gradual installation, in the 1960 s, of more efficient equipment for dust control. The increased use of dust suppression allowed study of large groups of textile workers exposed to mean levels of less than $1 \mathrm{mg}$ elutriated (or 'fine', or 'respirable') dust $/ \mathrm{m}^{3}$. Three studies published in the 1970 s constitute the entire literature on the subject of responses to very low levels of cotton dust. Merchant et al. (1973) studied 1784 workers exposed to dust in three cotton and two cotton-blend mills, with a control group of 798 workers in three synthetic/wool mills. These investigators concluded that, for workers in preparation and yarn areas, a safe level of exposure was at or below $0.1 \mathrm{mg} / \mathrm{m}^{3}$. A separate analysis for slashing and weaving areas was said to support a safe level of $0.75 \mathrm{mg} / \mathrm{m}^{3}$. Berry et al. (1974) studied 1006 operatives in 14 cotton mills and suggested that the need for a standard was met by a level of 
$0.5 \mathrm{mg} / \mathrm{m}^{3}$ (as fine dust, which would be roughly equivalent to $0.3 \mathrm{mg} / \mathrm{m}^{3}$ measured by the vertical elutriator). Fox et al. (1973) studied 1140 operatives in 11 cotton mills and concluded that a level of $0.37 \mathrm{mg} / \mathrm{m}^{3}$ would be expected to result in a $5 \%$ prevalence of byssinosis.

Given the difficulties peculiar to the study of byssinosis, some disagreement between results is not surprising. The major lesson to be learned from the present study is that a commonly used technique of data analysis can give rise to serious confusion about the relationship of dust dose and biological response. It is disturbing to note the ease with which a spurious dose-response curve could be derived from our data by combining or pooling data to analyse the effect of current dust levels. The average byssinosis rates by dust category are (Table 5): low $=1.3 \%$, intermediate $=2.7 \%$, and high $=10.6 \%$. For smokers only, the average rates in the respective categories are $2.1 \%, 3.3 \%$, and $14.4 \%$. Either set of rates, by comparison with the $3 \%$ prevalence observed in the synthetic/wool mill, could be used to contend that levels under $0.5 \mathrm{mg} / \mathrm{m}^{3}$ were demonstrably safe.

In our analysis, however, the observed variability of byssinosis prevalence could be explained by the distribution of the study population with respect to mill and job category, and to a lesser extent to smoking. Mean changes in lung function were more suggestive of adverse responses to current dust levels. The mean post-shift declines in $\mathrm{FEV}_{1.0}$ in both the intermediate and high exposure categories (Table 10) were twice as large as the decline in the control mill (Mill IV) and over three times as large as the decline in the low cotton dust exposure category. A putative threshold for the acute postshift functional decline is therefore at or near $\mathbf{0 . 2}$ $\mathrm{mg} / \mathrm{m}^{3}$ : another for byssinosis symptoms (from the first-order relationship, and disregarding the limitations in analysis discussed above) is at or near 0.5 $\mathrm{mg} / \mathrm{m}^{3}$. In this population we suggest that a level of cotton dust exposure which carries an acceptably low risk for byssinosis falls somewhere between 0.2 and $0.5 \mathrm{mg} / \mathrm{m}^{3}$. However, in view of the many potential influencing variables involved, it seems unrealistic to expect that a single standard applied to the entire cotton textile industry will be equally protective in all mills.

In searching for variables that might produce different biological response rates in each mill, one must immediately consider variations in biological potency of the airborne dust. Potency is related to the grade of raw cotton processed. This is not the only determinant, because spinning produces a less dangerous dust, milligram for milligram, than does carding cotton of the same grade. The substance causing byssinosis has yet to be identified, and this lack of ability to equate ambient dust levels with effective dosage is the major impediment to understanding the pathogenesis of byssinosis. In addition to this major uncertainty, other factors might operate to produce 'mill effects'. Borrowing a concept from infectious diseases, there are host and response variables to add to those imputed to the agent. The design of our study included population selection to examine host factors, especially effects of past exposure to cotton dust. During the week chosen for study it was our misfortune to find high cotton dust levels in the mill selected for past high exposure levels. The result was inability to separate the influences of past and present dust levels on byssinosis rates. Other host factors are possible, including innate propensities to develop symptoms and functional changes of airways obstruction in response to inhaled dusts. Race and sex have in the past been examined as risk factors, with inconclusive results (Merchant et al., 1973; Berry et al., 1974). Subjects with hyperreactive airways may leave the industry because of past high dust exposures in a particular mill, resulting in a remaining workforce that is relatively unresponsive to current dust levels. Atopy must receive consideration as a host factor influencing airways reactivity. Smoking is an example of an acquired host factor as well as a major confounding variable in assessment of symptoms and functional impairments. Response factors, or influences affecting detection of biological effects, could also be variable between mills. In a mill where dust levels were high in the past, many workers might respond positively to questions about current Monday chest tightness, based on their personal past experience with this symptom. Bias might also be introduced into questionnaire data in a mill where workers were highly concerned about the potential hazard of byssinosis and exhibited enhanced awareness of respiratory symptoms.

Ignoring distinctions in combining these and other variables to form dosage categories can therefore sacrifice information about those variables. It can also distort the dose-response relationship and can produce an apparent relationship that is not attributable to current dust levels at all. Variations in disease rate by mill or similar exposure unit should therefore be sought and analysed in large-scale prevalence studies. This suggestion is made with the recognition that mill effects are ultimately related, not to the strictly economic or industrial entities, but to more specific features of the relationships of agent, host and response.

\section{Acknowledgements}

The authors thank Sharon Anderson, Edna Lee, 
Christine McColloster and Joseph Beach for exceptional performance in the intensive data collection required under this protocol.

\section{References}

Barr, A. J., Goodnight, J. H., Sall, J. P., and Helwig, J. T. (1976). A User's Guide to $S A S$ 76, p. 127. SAS Institute, Raleigh, North Carolina.

Berry, G., Molyneux, M. K. B., and Tombleson, J. B. L. (1974). Relationships between dust level and byssinosis and bronchitis in Lancashire cotton mills. British Journal of Industrial Medicine, 31, 18-27.

Fox, A. J., Tombleson, J. B. L., Watt, A., and Wilkie, A. G. (1973). A survey of respiratory disease in cotton operatives. Part II. Symptoms, dust estimations, and the effect of smoking habit. British Journal of Industrial Medicine, 30, 48-53.

Higgins, J. E., and Koch, G. G. (1977). Variable selection and generalized chi-square analysis of categorical data applied to a large cross-sectional occupational health survey. International Statistical Review, 45, 51-62.

Leach, J. (1863). Surat cotton, as it bodily affects operatives in cotton mills. Lancet, 2, 648-649.

Medical Research Council (1960). Committee on the Aetiology of Chronic Bronchitis standardised questionnaire on respiratory symptoms. British Medical Journal, 2, 1665.

Merchant, J. A., Lumsden, J. C., Kilburn, K. H., O'Fallon, W. M., Ujda, J. R., Germino, V. H., and Hamilton, J. D.
(1973). Dose response studies in cotton textile workers. Journal of Occupational Medicine, 15, 222-230.

Roach, S. A., and Schilling, R. S. F. (1960). A clinical and environmental study of byssinosis in the Lancashire cotton industry. British Journal of Industrial Medicine, 17, 1-9.

Schilling, R. S. F. (1950). Byssinosis in the British cotton textile industry. British Medical Bulletin, 7, 52-56.

Schilling, R. S. F. (1956). Byssinosis in cotton and other textile workers. Lancet, 2, 261-265.

Schilling, R. S. F., Hughes, J. P. W., and Dingwall-Fordyce, I. (1955a). Disagreement between observers in an epidemiological study of respiratory disease. British Medical Journal, 1, 65-68.

Schilling, R. S. F., Hughes, J. P. W., Dingwall-Fordyce, I., and Gilson, J. C. (1955b). An epidemiological study of byssinosis among Lancashire cotton workers. British Journal of Industrial Medicine, 12, 217-227.

Schilling, R. S. F., Vigliani, E. C., Lammers, B., Valić, F., and Gilson, J. C. (1963). A report on a conference on byssinosis. In Proceedings of the XIV International Conference on Occupational Health, pp. 137-144. Excerpta Medica: Amsterdam.

Thomas, D. G. (1975). Exact and asymptotic methods for the combination of $2 \times 2$ tables. Computers and Biomedical Research, 8, 423-446.

US Department of Health, Education and Welfare (1974). Occupational Exposure to Cotton Dust: Criteria for a Recommended Standard, pp. 12-61. HEW Publication No. (NIOSH) 75-118. US Government Printing Office: Washington. 